\title{
Social Conflict in a Collection of Short Stories Mata Yang Enak Dipandang by Ahmad Tohari (Study of Literature Sociology)
}

\author{
Reni Oktavia ${ }^{1, *}$ Yasnur Asri ${ }^{1}$ \\ ${ }^{1}$ Indonesian Language Department, Universitas Negeri Padang, Padang, Indonesia \\ "Corresponding author. Email: renyoktavia9696@gmail.com
}

\begin{abstract}
This study aims to describe the forms of social conflict, the causes of the emergence of social conflicts, and the forms of social conflict resolution contained in the collection of short stories Mata Yang Enak Dipandang by Ahmad Tohari. This type of research is a qualitative research using descriptive method. The study used in this research is the study of the sociology of literature. The data sources for this research are short stories contained in the collection of short stories Mata Yang Enak Dipandang by Ahmad Tohari with a total of 15 short stories which were the second printing in 2015 with 216 pages. The data collection techniques in this study are: (1) reading and understanding the collection of short stories Mata Yang Enak Dipandang by Ahmad Tohari which examines social conflict as a data source; (2) marking data related to social conflicts contained in the collection of short stories Mata Yang Enak Dipandang by Ahmad Tohari using lines or numbers; (3) identifying or marking data based on forms of social conflict, causes of social conflict, and forms of social conflict resolution found in Ahmad Tohari's collection of short stories Mata Yang Enak Dipandang; and (4) taking an inventory of the data according to the object of research, based on the data inventory format. Based on the results of data analysis and discussion found 52 data. The results of the research in the collection of short stories Mata Yang Enak Dipandang by Ahmad Tohari are as follows. (1) The forms of social conflict in the collection of short stories Mata Yang Enak Dipandang by Ahmad Tohari, namely, (a) personal conflicts found 41 data, (b) racial conflicts found 4 data, (c) conflicts between social classes found 7 data; (2) The causes of social conflict in the collection of short stories Mata Yang Enak Dipandang by Ahmad Tohari, namely, (a) economic factors found 35 data, (b) biological factors found 1 data, (c) psychological factors found 11 data, and (d) cultural factors found 5 data; (3) Resolution of social conflicts in the collection of short stories Mata Yang Enak Dipandang by Ahmad Tohari, namely, (a) elimination (resignation) found 32 data, (b) subjugation (conquest) found 14 data, (c) Minority Consent (fair) found 2 data, and (d) compromise found 4 data.
\end{abstract}

Keywords: short story, social conflict, sociology of literature

\section{INTRODUCTION}

Social conflict is a conflict that occurs as a result of human social contact with other humans. Among the causes of social conflict are economic, cultural, and psychological factors [1]. The emergence of a conflict due to inconsistency in the thoughts and interests of several parties or groups that causes conflict between them but ends with a resolution. In general, social conflict can be said as a social process between two or more people when one party tries to get rid of the other party by destroying or making him insecure. Conflict is motivated by differences that are difficult to find in common or reconciled by two parties, both biological and economic differences such as intelligence, physical characteristics, knowledge, beliefs, and customs [2]. There are several factors whose nature is so complex that it causes social conflict, and social conflict does not just happen, but there are factors of ethnic strength, social class, inequality, and political opportunity [3].

There is a close relationship between literature and society. Literature is a reflection of society, so literature is born because there is society and the problems of life. One of the reasons a writer writes a work must be because of the influence of the surrounding environment. Literary works have a picture of a life that is appointed as a literary work. Literary works try to find hidden dimensions in human life, dimensions that are not reached by the quality of empirical evidence [4]. 
The problems that exist in society make literary writers creative in developing their ideas. Another reason why literature and society are related is that literary works are written by authors, told by storytellers, copied by copyists, and the three subjects are society; literary works live in society, absorb aspects of life that occur in society; literary works contain aesthetics, ethics, and logic, and society must be involved in this; and literary works are intersubjectivity, people find their own image in a work. From this statement, it can be said that various problems or conflicts that occur in the real and imaginary world can be expressed by the author in a literary work. Based on these problems, this study uses a literary sociologist approach.

As stated by Abdulsyani about sociology, which is part of the social sciences (social science) which together face society as its object. Another opinion was expressed by Sipayung that the sociology of literature is research that focuses on human problems. Because humans often express struggle in determining their future, based on imagination, feelings, and intuition. In this case, it is also explained that the sociology of literature studies two things, namely: first, the social context of the author, namely how the author gets a livelihood (protector, from the community or double work), for example, Chairil Anwar and Sutardji Calzoum Bachri who only work as poets. with the theatre. It is different with Sapardi Djoko Damono and Umar Kayam who are lecturers and writers, and other writers. Second, literature as a mirror of society: (a) literature may reflect society, (b) displaying social facts in society: loan sharks, forced marriage (Siti Nurbaya), diploma life (Novel Pada A Kapal by Nh. Dini), the lives of prostitutes (Rendra's Poetry Singing Angsa) and others.

Efforts to reveal literary works from the sociological aspect, Wellek and Warren, have the view that the relationship between literature and society can be classified as follows: (1) sociology of the author, which is concerned with social status, political ideology, and others. relating to the author; (2) sociology of literary works, which is to question about a literary work. The point is about what is implied in the literary work and what is the purpose or message to be conveyed; (3) sociology of literature which is concerned with the reader and its social influence on society.

Literary work is one of the author's objects in expressing a problem or conflict that occurs in human life and then poured into writing such as poetry, prose, and drama. Prose can be in the form of novels and short stories. Literary work is a form or form of life, both personal life and social life, although literary works in the form of fiction are in fact able to provide benefits in the form of moral values for readers. An author is able to describe various conflicts or problems that occur to humans with themselves, individuals with other individuals, as well as with the surrounding environment which is packaged in a creative process so as to produce a literary work with the aim of being a guide for readers to behave and act in accordance with norms prevailing in society. The social conflict can occur because of the form of conflict, the cause of the conflict and ending with the resolution of social conflict.

According to Soekanto, the form of social conflict consists of: (1) personal conflict, namely conflict that occurs in the heart or soul of a character he is a conflict experienced by humans with himself, he is more an internal problem of a human and conflicts that usually occur between two or more individuals because of differences in views and so on. personal conflicts that occur within a person and more than two individuals that can cause conflicts, disputes, and problems; (2) racial conflicts, namely, conflicts that generally arise due to racial differences, such as religion, differences in physical characteristics, interests and culture. These conflicts usually occur in societies where one race is the majority group; (3) conflict between social classes, namely, conflicts that occur between two different social classes due to differences in interests and social inequality [5]. For example, the rich and the poor, the government (ruler) with the people, workers and employers and so on.

According to Soekanto [5], forms of social conflict can be distinguished into several forms, including: (1) personal conflict, it is not uncommon for two people since they started to know each other to dislike each other. When bad beginnings are developed, mutual hatred arises. Each side tries to annihilate the opponent, curses are spoken, insults are thrown and so on until a physical fight may arise; (2) racial conflict, the parties will realize how there are differences between them which often cause conflict with each other. For example, the conflict between Negroes and whites in the United States; (3) conflict between social classes, caused by differences in interests, for example the interests of employers and workers; (4) political conflict, involving the groups of a society as well as between sovereign states; and (5) conflicts that are international in nature, caused by differences in interests which then seep into the sovereignty of the state. Based on some of these expert 
opinions, conflicts can occur starting from the smallest or from internal to external, both from individuals, groups, and in a wider scope. So that using Soekanto's theory Ahmadi namely: (1) personal conflict, (2) racial conflict, and (3) conflict between social classes [6].

According to Abdulsyani [7], there are four sources of the emergence of social conflict, including: (1) economic factors, such as poverty, unemployment, and so on. Poverty is defined as a condition in which a person is unable to take care of himself in accordance with the standard of living of the group and is also unable to utilize his mental and physical energy in the group. The factors that cause people to hate poverty are the realization that they have failed to get more than what they already have and the feeling of the absence of injustice; (2) biological factors, such as physical illnesses and disabilities; (3) psychological factors, such as neurological disease, mental illness, weak memory, convulsions drunk alcohol, difficulty adjusting, suicide, and others; and (4) cultural factors, such as problems of old age, homelessness, widowhood, divorce, crime, juvenile delinquency, religious, ethnic and racial disputes.

Soekanto [5], sees that there are several social problems that occur in the community, namely as follows: first, poverty. Poverty is a condition in which a person, family, or society cannot meet their normal needs. The problem of poverty is closely related to the problem of crime. Not infrequently a crime occurs because of the economic factor of the perpetrator. For example, theft or robbery which is usually motivated by poverty. Someone is desperate to steal or rob because they cannot fulfill their needs in a good way. Second, crime. According to Soekanto, crime is caused by the same social conditions and processes that produce other social behaviors. Crime acts can not only grow from the human itself, but also because of pressures that come from outside, such as the influence of work relationships, associations in certain social circles, all of which have elements of criminal acts. If the ratio of crimes increases, it is not impossible that it will cause unrest in the community, both the people who are directly affected by the crime, and the people in the surrounding environment.

Third, family disorganization. Soekanto says that family disorganization is the division of the family as a unit because its members fail to fulfill their obligations in accordance with their social role. Family disorganization includes, (a) incomplete family units due to relationships outside of marriage, (b) family disorganization due to relationships outside of marriage, (c) deficiencies in the family, namely in terms of communication with its members, (d) family crises. , because one who acts as the head of the family, beyond his own ability to leave the house, perhaps due to death, punishment, and because of war, (e) family crisis, caused by internal factors, such as mental balance of a family member or stress .

According to Soekanto [5], the problem of the younger generation is generally characterized by two opposing characteristics, namely the desire to fight (for example in the form of radicalism, delinquency of children, and so on) and apathy (blind adjustment to the moral standards of the older generation). . Resistance may be accompanied by a fear that society will be destroyed by deviant acts. While apathy is usually accompanied by a sense of disappointment towards society. Fifth, war. War is perhaps the most difficult social problem to solve in the history of human life. Because this problem involves several communities at once, so it requires international cooperation which until now has not been well developed. War is a form of conflict which every time ends with an accommodation.

Sixth, the problem of violation of community norms. According to Soekanto, the problem of violating community norms can be broadly categorized into four, namely prostitution; delinquency of children (violations committed by young people from certain social classes); alcoholism; and homosexuality. Seventh, the population problem. Indeed, the population problem is an important source of social problems to be addressed immediately. Population growth that is not controlled effectively can be an obstacle in the implementation of development. The impact of population imbalance is marked by uneven conditions, especially regarding the increasingly limited sources of human life.

Eighth, environmental problems. Salim says that the environment includes things that are caused by interactions between living organisms and the environment. Living organisms consist of humans, animals, and plants that individually or collectively affect and are influenced by the environment. Humans are the most dominant element in the environment. Humans have the ability to increase quantitatively and thanks to their minds humans are also able to improve themselves qualitatively, because humans are the dominant factor, the target is also aimed at the mutual influence between humans and their various aspects of the environment (ecosystem). This mutual influence can cause problems, be it problems of the social environment, the biological environment, or the physical environment. 
Ninth, the problem of bureaucracy. Bureaucracy is a hierarchical organization, which is applied rationally to coordinate the work of people for the purpose of carrying out administrative tasks. According to Santoso, bureaucracy is the entire government organization that carries out state duties in various government organizational units under departments, both central and regional, such as provinces, districts, sub-districts, and villages or kelurahan, the division of the scope of the bureaucracy is described in the following explanation: (1) Public Administration Bureaucracy, is a series of government organizations that carry out government tasks including maintaining order and security from the central level to the regions, namely provinces, districts, sub-districts, and villages or Ward. This task has a regulatory or regulatory function. (2) Development Bureaucracy, is a government organization that runs one specific sector in order to achieve development goals such as agriculture, health, education, and industry. (3) Service Bureaucracy, is a government organizational unit which is essentially part of or related to the community. Its main function is direct service to the community.

Based on the theory that has been disclosed, the research that will be carried out will use the theoretical basis put forward by Abdulsyani, namely: (1) economic factors, (2) biological factors, (3) psychological factors, and (4) cultural factors [8].

According to Ahmadi [6], there are several ways in solving social conflicts, namely: (1) elimination (resignation), namely, the resignation of one of the parties involved in the conflict expressed by: (a) we lose, (b) we sulk, (c) we quit, (d) we form our own group; (2) subjugation or domination, namely the person or party who has the greatest power can force another person or party to obey it; (3) minority consent (fair) means that the majority group wins, but the minority group does not feel defeated, and accepts the decision and agrees to carry out joint activities; (4) majority rule (most votes) means that the most votes are determined by voting, will determine the decision, without considering the arguments. In essence, majority is a form of subjugation; (5) compromise, namely both or all subgroups involved in the conflict try to find and get a middle path (half way); (6) integration (integration) ie conflicting opinions are discussed, considered and reviewed until the group reaches an agreement that satisfies all parties.

Based on the theory described above, the forms of social conflict resolution in the collection of short stories Mata Yang Enak Dipandang by Ahmda Tohari will be analyzed according to Ahmadi's opinion, namely: (1) elimination (resignation), (2) subjugation or domination (conquest), (3) minority consent (fair), (4) majority rule (most votes), (5) compromise (compromise), (6) integration (integration) [6].

One of the literary works is the short story. Short stories are a form of literary work in the form of fiction. Muhardi and Hasanuddin WS, state that fiction is a technique of reader manipulation so that the reader believes that the content it conveys really exists. The author creates fiction based on a problem as if it really happened or even happened. However, what he describes is the result of the author's imagination or imagination so that his work looks real. Therefore, it is hoped that the reader will be able to understand that every short story produced, whether the problem or the characters involved are fictitious or just imaginary. But overall, the fictional story described by the author is a complete picture of human life so that the short story becomes a reflection of various social problems that occur.

According to Thahar, short stories or better known as short stories are one of the most widely written types of fiction, usually they can be read in a short time or just a reading that is nothing more than a time barrier [9]. In connection with that, Hoeri in Suyitno, states that short stories are characters that are described through a series of events rather than the events themselves one by one [10]. What happens in it is usually an experience or colonization. Based on the explanation above, It can be concluded that the short story is a short story that has solid, complete content, has a unified problem and contains a deep impression and reveals a problem followed by the causes and consequences.

The research to be conducted is different from previous studies, it can be seen from the object and study to be carried out. The object of research that will be carried out this time is a collection of short stories Mata Yang Enak Dipandang by Ahmad Tohari using a sociological approach to literature. Other reasons are: first, the collection of short stories Mata Yang Enak Dipandang by Ahmad Tohari is used as an object of research because there are social conflicts that can be seen from the forms of social conflict, the causes of social conflict, and the resolution of social conflicts experienced by the characters based on problems related to economic factors as the main basis. Second, the collection of short stories Mata Yang Enak Dipandang by Ahmad Tohari, is a collection of short stories that have been published in various print media in 1983 and 1997, but were first 
recorded in 2013 and then reprinted in 2015 and 2019 so that the collection of short stories Mata Yang Enak Dipandang by Ahmad Tohari's work has been printed three times. Third, the collection of short stories Mata Yang Enak Dipandang by Ahmad Tohari has not yet conducted research on social conflict. Therefore, the researcher conducted a study with the title "Social Conflict in the Collection of Short Stories Mata Yang Enak Dipandang by Ahmad Tohari (Study of the Sociology of Literature). The collection of short stories Mata Yang Enak Dipandang will then be abbreviated or written as MYED.

\section{METHODS}

\subsection{Types and Research Methods}

This type of research is a qualitative research and uses content analysis techniques. The basis for implementing the content analysis method is interpretation. Interpretation in the qualitative method pays attention to natural situations, so the basis of interpretation in the content analysis method pays attention to the content of the message. According to Moleong qualitative research is research that produces analytical procedures that do not use statistical analysis procedures or other quantification methods [11]. Qualitative research is based on efforts to build their views which are examined in detail, formed with words, holistic and complex pictures. Based on the explanation above, the research will be conducted using qualitative research with descriptive analytical method. The choice of this method is because the data collected in the form of words, phrases, sentences, and discourses that come from the speech of the character or narrator contained in the collection of short stories Mata Yang Enak Dipandang by Ahmad Tohari. Analytical descriptive methods are not only used to reveal, describe, and explain but also provide explanations. Therefore, this study describes the forms of social conflict, the causes of social conflict, and the resolution of social conflicts contained in the collection of short stories Mata Yang Enak Dipandang by Ahmad Tohari.

\subsection{Data and Data Sources}

The data collected to describe social conflicts in this study are in the form of words, sentences, and discourses that are presented in descriptive form. The data of this research are words, sentences, exposure of the narrator, and the utterances of story characters as well as the actions of story characters contained in the collection of short stories Mata Yang Enak Dipandang by Ahmad Tohari.

The source of data in this study is a collection of short stories Mata Yang Enak Dipandang by Ahmad Tohari. This collection of short stories Mata Yang Enak Dipandang is published by PT Gramedia Pustaka Utama. This collection of short stories Mata Yang Enak Dipandang by Ahmad Tohari is the 2nd edition in 2015 which contains 15 short stories with 216 pages. The following are the titles contained in the collection of short stories Mata Yang Enak Dipandang by Ahmad Tohari, namely: (1) Mata Yang Enak Dipandang; (2) Bila Jebris Ada di Rumah Kami; (3) Penipu yang Keempat; (4) Daruan; (5) Warung Penajem; (6) Paman Doblo Merobek Layang-Layang; (7) Kang Sarpin Minta Dikebiri; (8) Akhirnya Karsim Menyebrang jalan; (9) Sayur Bleketupuk; (10) Rusmi Ingin Pulang; (11) Dawir, Turah, dan Totol; (12) Harta Gantungan; (13) Pemandangan Perut; (14) Salam dari Penyangga Langit; dan (15) Bulan Kuning Sudah Tenggelam.

\subsection{Research Instruments}

The research instrument is the researcher himself Researchers record and collect data using data recording sheets after the data is collected, then processed and interpreted. Furthermore, according to Moleong, that the researcher is a planner, implementer of data collection, analysis, data interpreter, and in the end he became the pioneer of the results of his research [11]. Researchers collect data by reading, identifying, classifying, and interpreting words, phrases, clauses, and sentences that can be abstracted as data on forms of social conflict contained in the collection of short stories Mata Yang Enak Dipandang by Ahmad Tohari.

\subsection{Data Collection Technique}

Data collection techniques in this study were carried out with the following steps:

- Read and understand the collection of short stories Mata Yang Enak Dipandang by Ahmad Tohari which examines social conflict as a data source.

- Marking data related to social conflicts contained in the collection of short stories Mata Yang Enak Dipandang by Ahmad Tohari using lines or numbers. 
- Identify or mark data based on forms of social conflict, causes of social conflict, and forms of social conflict resolution found in the collection of short stories Mata Yang Enak Dipandang by Ahmad Tohari.

- Inventory data according to the object of research, based on the data inventory format.

\subsection{Data Validation Techniques}

The data validation technique used in this study is a triangulation technique, namely a data validity checking technique that utilizes something that is born from outside the data for checking purposes or as a comparison against the data. In this study, checking or comparison of data is done by the researcher receiving input from the results of discussions with lecturers and also input from colleagues in proposal seminars.

\subsection{Data Analysis Techniques}

Analysis of the research data that has been collected is carried out with the steps described by Muhardi and Hasanuddin WS, which are as follows [12]:

- Classifying data related to forms of social conflict, causes of social conflict, and forms of social conflict resolution in the collection of short stories Mata Yang Enak Dipandang by Ahmad Tohari.

- Interpreting data on social conflict in the collection of short stories Mata Yang Enak Dipandang by Ahmad Tohari.

- Summarize the results of the analysis to see the forms of social conflict, the causes of the emergence of social conflicts, and the forms of social conflict resolution in the collection of short stories Mata Yang Enak Dipandang by Ahmad Tohari.

- Make a research report on social conflict in the collection of short stories Mata Yang Enak Dipandang by Ahmad Tohari.

\section{RESULTS AND DISCUSSION}

\subsection{Forms of Social Conflict}

\subsubsection{Personal Conflict}

Personal conflict is a conflict that occurs in the heart or soul of a character, it is a conflict experienced by humans with themselves, it is more an internal problem of a human being and conflicts that can occur between two or more individuals due to differences in views and so on. Personal conflicts that occur within a person and more than two individuals can cause conflict in the collection of short stories Mata Yang Enak Dipandang by Ahmad Tohari. The personal conflict can be seen from the collection of short stories Mata Yang Enak Dipandang, namely Mata Yang Enak Dipandang totaling five data, Bila Jebris Ada di Rumah Kami totaling one data, Penipu yang Keempat three data, Daruan five data, Warung Penajem two data, Paman Doblo Merobek Layanglayang is one data, Kang Sarpin Minta Dikebiri is two data, Akhirnya Karsim Menyebrang Jalan is one data, Sayur Bleketuplek is four data, Dawir Turah dan Totol is one data, Harta Gantungan is one data, Pemandangan Perut a total of seven data, Salam Dari Penyangga Langit a total of three data, Bulan Kuning Sudah Tenggelam a total of six data.

In the short story Mata Yang Enak Dipandang by Ahmad Tohari, there are forms of social conflict, namely personal conflict. Personal conflict is a conflict that occurs within a character that is experienced by humans with themselves, it can be said as an internal problem of a human being and conflicts that can occur between two or more individuals due to differences in views that cause a dispute, disagreement and squabble. It can be seen in the MYED data, 2015:9/MYED/KP as follows:

Tadi pagi Tarsa sengaja membimbing Mirta sedemikian rupa sehingga kaki Mirta menginjak tahi anjing. Mirta boleh mendesis dan mengumpat sengit. Tapi Tarsa tertawa, bahkan mengancam akan mendorong Mirta ke dalam got kecuali Mirta mau memberi sebatang rokok. Sebelum itu, Tarsa menolak perintah Mirta agar ia berjalan agak lambat. Perintah itu baru dipenuhi setelah Mirta membelikannya lontong ketan

Based on the quote above, Mirta has the most personal conflict with Tarsa's treatment. Because Tarsa purposely directed Mirta so that his feet would step on dog droppings which made Mirta angry. Tarsa knows that whatever he does to Mirta will not make Mirta angry, so often Tarsa does these things to Mirta. So there are always disputes between them. Even so, Mirta cannot fight because Mirta's life depends on Tarsa who always leads him to beg every day. however Tarsa has helped him walk even though only used by Tarsa. Mirta realized this but he could not leave Tarsa. This personal conflict involved two people, namely Mirta and Tarsa. This is in 
accordance with the opinion of Soekanto, which states that personal conflict is a conflict that occurs in the heart or soul of a character, it is a conflict experienced by humans with themselves, it is more an internal problem of a human being and ordinary conflicts. occurs between two or more individuals because of differences in views and so on

\subsection{Racial Conflict}

Racial conflict is a conflict that generally arises due to racial differences, such as religion, differences in physical characteristics, interests and culture. This conflict usually occurs in a society where one race is the majority group. The racial conflict can be seen from the collection of short stories Mata Yang Enak Dipandang, namely

Bila Jebris Ada Dirumah Kami totaling one data, Warung Penajem totaling one data, and Rusmi Ingin Pulang totaling two data.

In the short story Bila Jebris Ada Di Rumah Kami by Ahmad Tohari, it can be seen in the following quote:

Orang bilang bahwa Jebris anak yang mujur ketika mereka melihat Ibu muda itu mulai dipercaya menjaga kios suaminya yang lumayan besar. Namun satu tahun kemudian, sudah terdengar selentingan bahwa dalam berdagang Jebris meniru emaknya. Jebris akrab dan hangat dengan sopir-sopir, kernet-kernet, dan tukang ojek. Kiosnya selalu meriah dengan irama musik gendang dan tawa anak-anak muda. Lalu Jebris kedapatan menghilang bersama Gobyok. Tukang ojek yang langsing dan berkulit manis.

Ketika itupun orang bilang, "Tidak heran, Jebris meniru emaknya penjual gembus itu. Apa kamu tidak tahu gembus bisa berarti macam-macam?"

$$
\text { Based on data from MYED, }
$$

2015:26/BJADRK/KR, Jebris experienced conflicts with his neighbors living in the area. Jebris feels cornered and is considered a woman selling gembus to men who stop by her shop. It can be seen in the following quote "When even then people said, No wonder, Jebris imitated the gembus seller's mother. Don't you know gembus can mean all kinds of things?" This social conflict is a racial conflict experienced by Jebris with the surrounding community, because Jebris has been considered to have done things that are not in accordance with the teachings of his religion. This is in line with Soekanto's opinion, racial conflict is a conflict that generally arises due to racial differences, such as religion, differences in physical characteristics, interests and culture. This conflict usually occurs in a society where one race is the majority group.

\subsection{Social Class Conflict}

Conflict between social classes is a conflict that occurs between two different social classes because of differences in interests and social inequality. For example, the rich and the poor, the government (ruler) with the people, workers and employers and so on Conflicts between social classes that occur on several parties can cause conflict in the collection of short stories Mata Yang Enak Dipandang by Ahmad Tohari.

The conflict between social classes can be seen from the collection of short stories Mata Yang Enak Dipandang, namely Bila Jebris Ada Di Rumah Kami totaling one data, Paman Doblo Merobek Layang-Layang amounting to one data, Akhirnya Karim Menyebrang Jalan two data, Sayur Bleketuplek two data, Dawir, Turah, Dan Totol amount to one data.

In the short story Bila Jebris Ada Dirumah Kami by Ahmad Tohari, the following data are found:

"Nak Ratib, sudah dua hari Jebris tidak pulang. Pagi tadi ada orang melihat Jebris di kantor polisi. Dihukum."

"Dihukum?"

"Ya. Kalau tidak dihukum, mengapa Jebris ada di kantor polisi? Nak Ratib, kasihan si mendol. Dia tak mau makan dan menangis minta menyusu emaknya."

"Jadi?"

"Nak Ratib, aku tidak tahu harus berbuat apa."

"Ya. Kakek sudah terlalu lemah. Kakek tinggal saja di rumah. Biar aku yang menyusul Jebris dan bila mungkin membawanya pulang," kata Ratib.

Based on MYED data, 2015:27/BJADRK/KAS,a conflict occurred between Jebris and the police. The reason, someone saw Jebris at the police station. Jebris is famous as a night woman who is often caught in police raids, as can be seen in the conversation between Jebris and Ratib's father as follows: "Son Ratib, Jebris has not been home for two days. This morning someone saw Jebris at the police station. Sentenced." The social conflict that occurred between Jebris and the police was a conflict between social classes because there were differences in interests between the government and the people. Jebris had no other choice, but to work as a night woman to fulfill his needs while the police only carried out their duties according to orders. This is in accordance with the 
opinion of Soekanto, conflict between social classes is a conflict that occurs between two different social classes due to differences in interests and social inequality. For example, the rich and the poor, the government (ruler) with the people, workers and employers and so on.

\subsection{Causes of Social Conflict}

\subsubsection{Economic Factor}

Economic factors are the cause of the emergence of social conflicts in the collection of short stories Mata Yang Enak Dipandang by Ahmad Tohari including poverty, unemployment, and so on. The causes of the emergence of social conflicts that are seen from economic factors are found in the short story Mata Yang Enak Dipandang which consists of four data. Furthermore Bila Jebris Ada di Rumah Kami a total of three data. Short story Penipu yang Keempat consists of three data. The short story Daruan consists of five data. Short story Paman Doblo Merobek Layang-layang consists of two data. Short story Akhirnya Karsim Menyebrang Jalan consists of three data. Short stories Sayur Bleketuplek consist of six data. Short story Rusmi Ingin Pulang consists of two data. Short story Dawir Turah dan Totol consists of two data. The short story Bulan Kuning Sudah Tenggelam consists of five data.

The causes of the emergence of social conflicts contained in the short story Mata Yang Enak Dipandang by Ahmad Tohari can be seen in the following MYED data, 2015:10/MYED/FE:

Mirta jengkel dan tidak ingin diperas terus menerus. Ia akan mencoba bertahan. Maka meski kepalanya serasa diguyur pasir pijar dari langit, Mirta tak ingin memanggil Tarsa. Berkali-kali ditelannya ludah yang pekat. Ditahannya rasa pening yang menusuk ubun-ubun. Diusapnya wajah yang mencoba meredam rasa panas yang menjereng.

In the data above, it can be seen that the cause of the emergence of social conflicts in the short story Mata Yang Enak Dipandang is caused by economic factors, namely the problem of poverty. Mirta is always being blackmailed continuously and trying to survive as hard as he can, he is forced to earn money by begging and Mirta has to do all his orders. Living poor and very deprived makes Tarsa and Mirta have to become beggars. The conflict between the two is caused by economic factors, such as the opinion of Abdulsyani, which says that economic factors are the first factors that can cause conflicts such as poverty, unemployment, and so on.
Poverty is usually described as a lack of income to meet the basic necessities of life. The most basic needs include food, clothing and shelter. The problem of poverty is closely related to the problem of crime.

\subsubsection{Biological Factor}

Biological factors are factors that cause social conflict due to diseases that exist in the human body. There is only one biological factor in the collection of short stories Mata Yang Enak Dipandang by Ahmad Tohari, namely the short story Mata Yang Enak Dipandang by Ahmad Tohari.

The causes of the emergence of social conflicts contained in the short story Mata Yang Enak Dipandang by Ahmad Tohari can be found in MYED, 2015:9/MYED/FB as follows::

Tadi pagi Tarsa sengaja membimbing Mirta sedemikian rupa sehingga kaki Mirta menginjak tahi anjing. Mirta boleh mendesis dan mengumpat sengit. Tapi Tarsa tertawa, bahkan mengancam akan mendorong Mirta ke dalam got kecuali Mirta mau memberi sebatang rokok. Sebelum itu, Tarsa menolak perintah Mirta agar ia berjalan agak lambat. Perintah itu baru dipenuhi setelah Mirta membelikannya lontong ketan.

In the data above, it can be seen that the cause of the emergence of social conflicts that occurred between Mirta and Tarsa was caused by biological factors. Mirta who has a physical disability, namely blindness, makes Tarsa take arbitrary actions against Mirta, as in the quote "This morning Tarsa deliberately guided Mirta in such a way that Mirta's foot stepped on dog droppings." Based on the actions taken by Tarsa against Mirta resulting in a conflict between the two caused by biological factors, namely there is a physical deficiency or disability experienced by Mirta. As the opinion of Abdulsyani which states that one of the causes of the emergence of social conflict is biological factors, namely a conflict caused by physical illnesses and disabilities.

\subsubsection{Psychological Factor}

Psychological factors are factors that cause the emergence of social conflicts caused by neurological diseases, suicide, mental disorganization or psychiatric problems.

Psychological factors contained in the collection of short stories Mata Yang Enak Dipandang rich in Ahmad Tohari are found in short stories Kang Sarpin Minta Dikebiri totaling two data, Pemandangan Perut totaling 
six data, short stories Salam Dari Penyangga Langit totaling two data, short stories Bulan Kung Sudah Tenggelam amounting to one data.

In the short story Kang Sarpin Minta Dikebiri by Ahmad Tohari there are causes for the emergence of social conflicts, namely the following MYED data, 2015:78/KSMD/FP:

"Ya, wong gemblung itu sudah meninggal," kata Dalban dengan enak. Wajahnya tampak tanpa beban. "Bagaimana aku tak menyebut iparku itu wong gemblung? Coba dengar. Suatu ketika di kilang padi, orang-orang menantang Sarpin: bila benar jantan, dengan upah lima ribu rupiah dia harus berani membuka celana di depan orang banyak. Mau tahu tanggapan Sarpin? Tanpa pikir panjang Sarpin menerima tantangan itu. Ia menelanjangi dirinya bulat-bulat di depan para penantang. Lalu enak saja, dengan kelamin berayunayun dia berjalan berkeliling sambil meminta upah yang dijanjikan."

Based on the two data above, the cause of the emergence of social conflict is due to psychological factors suffered by Sarpin. He is not like other normal humans in the sense that he has a mental disorder, so he causes a lot of conflict in his own family because he feels ashamed to have Sarpin. This can be seen clearly when Sarpin's brother-in-law tells the neighbours about the bad things that Sarpin did during his life. As the opinion of Abdulsyani, which states that psychological factors are one of the causes of the emergence of conflict, including such as neurological disease, mental illness, weak memory, convulsions drunk alcohol, difficulty adjusting, suicide, and others.

\subsubsection{Cultural Factor}

Cultural factors are the cause of the emergence of social conflicts caused by problems of old age, homelessness, widowhood, divorce, crime, juvenile delinquency, religious, ethnic and racial disputes.

Cultural factors contained in the collection of short stories Mata Yang Enak Dipandang by Ahmad Tohari can be seen in short stories Warung Penajem totaling three data, short stories Harta Gantungan amounting to one data, and Salam Dari Penyangga Langit totaling one data.

In the short story Warung Penajem by Ahmad Tohari there are causes for the emergence of social conflicts, namely the following MYED data, 2015:59/WP/FK:
"Oalah, Kang, bedanya banyak. Karena cuman main-main, begitu-begitu yang saya lakukan itu tidak sampai ke hati. Tujuan saya hanya untuk membayar penajem agar warung kita laris, tidak lebih. Jadi kamu tak kehilangan apa-apa, Kang. Semuanya utuh. Kang, jika warung kita bertambah laris, kita juga yang bakal enak-kepenak, bukan?"

Belum, satu detik setelah Jum selesai mengucapkan kata-katanya, Kartawi bangkit. Detik beriku terdengar suara gelas hancur terbanting di lantai. Kartawi keluar setelah membanting pintu keras-keras. Dan Jum menangis.

Based on the data above, it can be seen that the cause of the emergence of social conflict is due to cultural factors. The debate that occurred between Kartawi and Jum occurred because Jum gave a penjem in the form of himself or gave his body to Koyor, who is a village shaman so that the stall they have can sell well and be busy. Penajem here is a condition that must be given to the shaman so that what he wants can be achieved, the pentajem given can be in the form of money, cemani chicken or his own body. It was Jum's choice to give his body to a dukun that made Kartawi angry and disapproved. Giving Penajem is the right of every person, but it is related to the mystical which is contrary to the religion he adheres to so that it is not in line with the rules of his religion. As the opinion of Abdulsyani, which states that cultural factors, such as problems of old age, having no place of residence, widowhood, divorce, crime, juvenile delinquency, religious, ethnic and racial disputes.

\subsection{Resolutions of Social Conflict}

\subsubsection{Elimination}

The form of social conflict resolution in this case is elimination (resignation), namely, the resignation of one of the parties involved in the conflict expressed by: (a) we lose, (b) we resent, (c) we leave, (d) ) we formed our own group. The form of social conflict resolution contained in the collection of short stories Mata Yang Enak Dipandang by Ahmad Tohari, namely in the short story Mata Yang Enak Dipandang consists of four data.

Furthermore short stories Bila Jebris Ada di Rumah Kami amounted to one data. Short story Penipu yang Keempat consists of two data. Short story Daruan consists of four data. Short story Warung Penajem consists of three data. Short story Paman Doblo Merobek 
Layang-layang consists of two data. Short stories Kang Sarpin Minta Dikebiri amount to one data. Short story Akhirnya Karsim Menyebrang Jalan consists of three data. Short stories Rusmi Ingin Pulang Short stories Pemandangan Perut totaling five data. Short story Salam Dari Penyangga Langit consists of three data. Short story Bulan Kuning Sudah Tenggelam consists of three data.

In the short story Mata Yang Enak Dipandang by Ahmad Tohari, there are forms of conflict resolution found in the following data:

Mirta jengkel dan tidak ingin diperas terus menerus. Ia akan mencoba bertahan. Maka meski kepalanya serasa diguyur pasir pijar dari langit, Mirta tak ingin memanggil Tarsa. Berkali-kali ditelannya ludah yang pekat. Ditahannya rasa pening yang menusuk ubun-ubun. Diusapnya wajah yang mencoba meredam rasa panas yang menjereng.

Based on the data above, it can be seen that the resolution of social conflicts is elimination. Elimination conflict resolution can be seen in the MYED data, 2015:10/MYED/E, the conflict between Mirta and Tarsa ended in elimination or (resignation) from Mirta by giving in and not wanting to continue the debate. The irritability experienced by Mirta made him resign himself to all the actions and treatment given by Tarsa because he did not have the power and strength to fight Tarsa. Based on this, Mirta's actions are included in the resignation of one of the conflicting parties so that this is in accordance with Ahmadi's opinion, which states that there are several ways to resolve social conflicts, one of which is elimination. is the resignation of one of the parties involved in the conflict expressed by: (a) we lose, (b) we resent, (c) we leave, (d) we form our own group.

\subsubsection{Subjugation (Penaklukan)}

The form of social conflict resolution in this case is subjugation, where the person or party who has the greatest power can force another person or party to obey it. The form of subjugation settlement (conquest) can be seen in the collection of short stories Mata Yang Enak Dipandang by Ahmad Tohari. In the short story Penipu Yang Keempat the resolution of social conflicts is one data. Sayur Bleketuplek totaling six data. Short stories Rusmi Ingin Pulang amount to one data. Short story Dawir Turah dan Totol consists of two data. Harta Gantungan amounted to one data. Short stories Pemandangan Perut amount to one data. Bulan Kuning Sudah Tenggelam totaling two data.
In the short story of the Penipu Yang Keempat by Ahmad Tohari, there is a form of conflict resolution, namely subjugation. It can be seen in the following data:

Seperti ular kehilangan mangsa yang sudah dililitnya, laki-laki dari Cikokol itu termangu sendiri. Namun, matanya yang licik dan awas mengalihkan pandangan kepadaku. Oh, ternyata orang memang mudah tertipu.

Lihatlah lelaki cikokol itu pangling hanya karena aku berganti pakaian. Dia mendekatiku, dan aku siap menikmati tipuannya yang kedua. Dari jarak beberapa langkah, kulihat dia menunduk dan mimik wajahnya mendadak berubah. Bukan main, dia kelihatan seperti orang yang sangat bingung.

Based on the MYED data, 2015:36/PYK/S above, it can be seen that the form of social conflict resolution is subjugation. Because, a fraudster who tries to carry out his action by offering some goods at an unreasonable price to his potential victim is confused and he does not realize that the victim actually knows his action. After a while he realized that the victim was smarter and the scammer couldn't do anything about it. As the opinion of Ahmadi, which states that subjugation is a person or party who has the greatest power to force another person or party to obey it.

\subsubsection{Minority Consent}

The form of social conflict resolution in this case is minority consent (fair), meaning that the majority group wins, but the minority group does not feel defeated, and accepts the decision and agrees to carry out joint activities. The form of Minority Consent (Fair) conflict resolution in the collection of short stories Mata Yang Enak Dipandang by Ahmad Tohari is contained in the short story Bila Jebris Ada di Rumah Kami totaling one data. Furthermore Bulan Kuning Sudah Tenggelam amounted to one data.

Resolution of social conflicts contained in the short story Bila Jebris Ada Di Rumah Kami Ahmad Tohari, namely on MYED, 2015: 28/BJADRK/MC:

"Kang Ratib, jadi kamu hendak mengambil Jebris dari kantor polisi?"

"Ya. Dan kuharap kamu tidak keberatan"

"Lalu"

“Juga bila kamu tidak keberatan, Jebris kita coba ajak bekerja di rumah kita. Mungkin dia bisa masak dan cuci pakaian”. 
"Andaikan dia mau, apakah kamu tidak merasa risih ada pelacur di antara kita?"

"Ya ada risinya juga, tapi mungkin ini jalan yang bisa kita tempuh.”

\section{"Bila jibris tidak mau?"}

"Kita akan terus bertetangga dengan dia. Dan kamu tidak usah khawatir malaikat pembawa berkah tidak akan datang ke rumah ini bila kamu tetap punya kesabaran dan sedikit empati terhadap anak penjual gembus itu."

Based on data from MYED, 2015:28/BJADRK/MC, using a form of conflict resolution with minority consent (fair). This means that even though the majority group wins, the minority group or other parties do not feel disadvantaged. Ratib is the majority party because as the head of the family makes a decision and his wife accepts and follows what has been determined by her husband. That way, the form of resolving social conflicts that occur is using minority consent (fair). According to Ahmadi, minority consent (fair) is the majority group who wins, but the minority group does not feel defeated, and accepts the decision and agrees to carry out joint activities.

\subsubsection{Compromise (Kompromi)}

The form of social conflict resolution in this case is compromise, where both or all subgroups involved in the conflict try to find and get a middle path (half way). The form of settlement of compromise (compromise) in the collection of short stories Mata Yang Enak Dipandang by Ahmad Tohari is found in the Mata Yang Enak Dipandang short story, totaling one data. Furthermore Bila Jebris Ada di Rumah Kami amounted to one data. Short stories Daruan amount to one data. Short stories Kang Sarpin Minta Dikebiri amount to one data.

In the short story Mata Yang Enak Dipandang by Ahmad Tohari, the form of social conflict resolution is found in the following data:

"Kamu yang punya mata. Seharusnya kamu bisa melihat orang yang biasanya mau kasih recehan. Didepan seperti itu kita harus lama bertahan"

"Omong kosong. Bagaimana bisa aku mengenali orang seperti itu?'

"Betul, kan? Kamu memang tolol. Perhatikan mata mereka. Orang yang suka memberi receh punya mata lain.” lain?"
"Sudah kubilang, aku puluhan tahun jadi pengemis. Kata teman-teman yang melek, mata orang yang suka memberi memang beda."

"Tidak galak?"

"Ah, betul! Itu dia. Dari tadi aku mau bilang begitu. Tarsa, kamu betul. Mata orang yang suka memberi tidak galak. Mata orang yang suka memberi, kata teman-teman yang melek, enak dipandang. Ya, kukira betul; mata orang yang suka memberi memang enak dipandang. '”

Tarsa nyengir. Ada suara gemuruh dan sunyi rem logam yang menggurat telinga. Kereta masuk.

"Akan kucari penumpang-penumpang yang matanya enak dipandang. Ayo, kang Mirta, kita jalan"

In MYED data, 2015:14/MYED/C, the form of social conflict resolution is using compromise. It can be seen in the quote: The debate that took place between Mirta and Tarsa ended in a mutual agreement. Finally Tarsa accepted Mirta's advice and input to beg for people whose eyes were pleasing to the eye. If they want to get more begging results, they have to do a new strategy, which is to look for people's eyes that are pleasing to the eye and Tarsa accepts Mirta's advice. In this regard, agree with Ahmadi, which states that compromise is that both or all subgroups involved in the conflict try to find and get a middle way (half way).

\section{CONCLUSION}

Based on the results of research and discussion of social conflicts in the collection of short stories Mata Yang Enak Dipandang by Ahmad Tohari, it can be concluded that the forms of social conflict contained in the collection of short stories Mata Yang Enak Dipandang by Ahmad Tohari found 52 data. From the overall data obtained, there are more forms of personal conflict experienced by the characters in the short story. Whether it's conflict with himself or with others. This can be seen in the following description: (a) personal conflicts found 41 data, (b) racial conflicts found 4 data, (c) conflicts between social classes found 7 data.

The causes of social conflicts in the collection of short stories Mata Yang Enak Dipandang by Ahmad Tohari are influenced by economic factors as a whole. Ahmad Tohari in his short story collection this time departs from the lives of small people in defending their lives. Tells the situation of the people below who live in a rural setting as well as people on the outskirts of the city and the homeless. In addition, family problems such as 
communication that does not go well can lead to social conflict. It can be seen in the following description: (a) economic factors found 35 data, (b) biological factors found 1 data, (c) psychological factors found 11 data, and (d) cultural factors found 5 data.

Resolution of social conflicts in the collection of short stories Mata Yang Enak Dipandang by Ahmad Tohari is mostly done by elimination. The characters involved in the conflict do not have great power to defend the opinions they have so they choose to leave the conflict or just accept whatever happens. Even as parties who do not have great power, conflicting figures are forced to accept or carry out all decisions made by the majority or those in power. This can be seen in the following description: (a) elimination (resignation) found 32 data, (b) subjugation (conquest) found 14 data, (c) Minority Consent (fair) found 2 data, and (d) compromise (compromise).

\section{ACKNOLEDGMENT}

The author thanks Prof. Dr. Yasnur Asri, M.Pd., who has provided guidance and thoughts to direct the author in completing this research. The author would also like to thank the two reviewers, Dr. Yenni Hayati, S.S., M. Hum., and Dr. Nurizzati, M. Hum. who has provided suggestions and input for the perfection of the author's writing.

\section{REFERENCES}

[1] Saputri et al, "Konflik Sosial pada Novel Warisan karya Chairul Harun," Jurnal Pendidikan Bahasa dan Sastra Indonesia, pp. 52-58, 2016.

[2] A. A. Nugraha, "Konflik Sosial pada Novel Lelaki Harimau Karya Eka Kurniawan," in SENASBASA (Seminar Nasional Bahasa dan Sastra), Malang, 2019.

[3] M. Ulum, "Konflik Sosial dalam Cerpen Kabut Ibu Karya Mashdar Zainal," in SENASBASA (Seminar Nasional Bahasa dan Sastra), Malang, 2019.

[4] Nuraeni et al, "Konflik Sosial dalam Cerpen Pengunyah Sirih, Menjaga Perut dan Ikan Terbang Kufah Melalui Pendekatan Sosiologi Sastra," Jurnal Literasi, vol. 4, no. 2, pp. 114-120, 2020.
[5] S. Soekanto, Sosiologi Suatu Pengantar, Jakarta: Raja Grafindo Persada, 2017.

[6] A. Ahmadi, Psikologi Sosial, Jakarta: Rineka Cipta, 2009.

[7] Abdulsyani, Sosiologi: Skematika, Teori, dan Terapan, Jakarta: Bumi Aksara, 2012.

[8] Abdulsyani, Sosiologi: Skematika, Teori, dan Terapan, Jakarta: Bumi Aksara, 2012.

[9] H. E. Thahar, Menulis Kreatif Panduan Bagi Pemula, Padang: UNP Press, 2008.

[10] Suyitno, Apresiasi Puisi dan Prosa, Solo: Sebelas Maret University Press, 2009.

[11] L. Moleong, Metodologi Penelitian Kualitatif, Bandung: Remaja Rosdakarya, 2010.

[12] Muhardi and H. W.S, Prosedur Analisis Fiksi, Padang: Citra Budaya Indonesia, 2006. 